\title{
A New HPLC-ELSD Method To Quantify Indican in Polygonum tinctorium L. and To Evaluate -Glucosidase Hydrolysis of Indican for Indigo Production
}

\author{
Angelini, LG
}

http://hdl.handle.net/10026.1/9313

10.1021/bp0300218

Biotechnology Progress

Wiley

All content in PEARL is protected by copyright law. Author manuscripts are made available in accordance with publisher policies. Please cite only the published version using the details provided on the item record or document. In the absence of an open licence (e.g. Creative Commons), permissions for further reuse of content should be sought from the publisher or author. 


\title{
A New HPLC-E LSD Method To Quantify Indican in Polygonum tinctorium L. and To Evaluate $\beta$-Glucosidase Hydrolysis of Indican for Indigo Production
}

\author{
Luciana G. Angelini,*,† Elisabetta Campeol,† Sabrina Tozzi,† Kerry G. Gilbert, § \\ David T. Cooke, $\S$ and Philip J ohn ${ }^{\ddagger}$
}

Dipartimento di Agronomia e Gestione dell'Agroecosistema, Università di Pisa, via S.Michele degli Scalzi 2, 56100 Pisa, Italy; School of Plant Sciences, The University of Reading, Reading RG6 6AS, UK; and Department of Biological Sciences, University of Bristol, IACR Long Ashton Research Station, Long Ashton, Bristol BS41 9AF, UK

\begin{abstract}
A method to quantify the indigo precursor indican (indoxyl- $\beta$-D-glucoside) in Polygonum tinctorium L. has been developed. Plant material was extracted in deionized water, and indican was identified and quantified using high performance liquid chromatography (HPLC) coupled to an evaporative light scattering detector (ELSD). Results confirmed that with this method it is possible to measure indican content in a short time, obtaining reliable and reproducible data. Using this method, leaf indican content was quantified every 15 days during the growing season (from May to October) in P. tinctorium crops grown in a field experiment in Central I taly. Results showed that indican increased al ong the growing season until flowering and was positively affected by photosynthetic active radiation (PAR). Indican is naturally hydrolyzed by native $\beta$-glucosidase to indoxyl and glucose, the indoxyl yielding indigo. The activity of two enzymes, sweet almond $\beta$-glucosidase and Novarom G preparation, were compared with P. tinctorium native $\beta$-glucosidase to evaluate indigo production. Results showed that the ability to promote indigo formation increased as follows: al mond $\beta$-glucosidase $\leq$ Novarom G.
\end{abstract}

\section{Introduction}

Indican (indoxyl- $\beta$-D-glucoside) is a precursor of the blue dye indigo and is present in large amounts in Polygonum tinctorium L. leaves. When leaves are broken the indican is hydrolyzed to indoxyl and glucose by the native $\beta$-glucosidase located in chloroplasts of mesophylls cells (1). Scheme 1 outlines the spontaneous conversion of the free indoxyl by air oxidation into indigo. $\beta$-Glucosidase from $\mathrm{P}$. tinctorium was fully characterized by Minami et al. $(1,2)$, who found that its optimum $\mathrm{pH}$ is about 6.5, much higher than that of other glucosidases, which are generally found in the range from 4 to 5 . Furthermore, it showed specifically a low $\mathrm{K}_{\mathrm{m}}$ for indican at $0.34 \mathrm{mM}$, which is about 2 orders of magnitude lower than that of the sweet almond enzyme. $\beta$-Glucosidase also reacted with other $\beta$-glucosides conjugated with aromatic groups but not with $\alpha$-glucosides or other glycosides such as galactosides $(1,2)$.

Following traditional methods $(3,4)$, indigo is obtained by the action of native $\beta$-glucosidase on a water extract of Polygonum tinctorium leaves at temperature between 25 and $60{ }^{\circ} \mathrm{C}$.

Recently Maugard et al. (5) have compared the indican hydrolysis activity of two commercial preparations of $\beta$-1,4-gl ucosidase, Novozym 188 and Novarom G, on indican hydrolysis. They described a HPLC-UV method to determine indican content in P. tinctorium leaves and

\footnotetext{
† Università di Pisa.

₹ The University of Reading

$\S$ University of Bristol.
}

to follow the effects of the two commercial enzyme preparations on indican hydrolysis in a water extract at $30{ }^{\circ} \mathrm{C}$. Under these temperature conditions the activity of native $\beta$-glucosidase is not lost, whereas it was completely inactivated at $60{ }^{\circ} \mathrm{C}(2)$. For this reason, in a $30^{\circ} \mathrm{C}$ water extract it is difficult to evaluate the activity of synthetic enzymes for the simultaneous activity of native $\beta$-glucosidase that is extracted under these conditions.

Evaporative light-scattering detectors (ELSD) have recently been introduced for HPLC systems to analyze any compound that has sufficiently lower volatility than the mobile phase. The principle of its operation involves nebulization of the column effluent to form an aerosol, followed by solvent evaporation in a heated drift tube and then the detection of the remaining nonvolatile solute particles in the light scattering cell. The use of ELSD eliminates the common problems associated with other HPLC detectors; it can achieve stable baselines with multisolvent gradients for improved resolution and faster separations $(6,7)$.

In the present paper a HPLC-ELSD method to identify and quantify indican in P. tinctorium leaves is described in order to assess indican seasonal variation in field grown plants and to evaluate $\beta$-glucosidase hydrolysis of indican for indigo production. A comparison between the activity of two commercial enzymes, sweet almond $\beta$-glucosidase and Novarom G preparation, was carried out using as substrates standard indican and a $100^{\circ} \mathrm{C}$ water extract of Polygonum tinctorium. Furthermore, we compare the activity of these two enzymes on the $100^{\circ} \mathrm{C} P$. 
Scheme 1

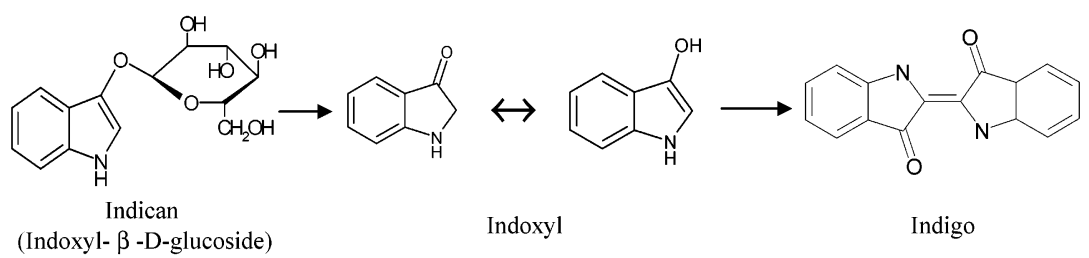

tinctorium water extract with that of native $\beta$-glucosidase on a $25^{\circ} \mathrm{C}$ water extract, evaluating indigo production by spectrophotometric analysis. This study contributes to our knowledge of P. tinctorium as a new industrial crop for natural indigo production.

\section{Experimental Procedures}

2.1. Biological and Chemical Material. Indican standard (particle size between 0.06 and $0.08 \mathrm{~mm}$ ) was obtained from Sigma Chemical Co. (USA). Almond $\beta$-glucosidase was obtained from Biochemica $(6.3 \mathrm{U} / \mathrm{mg}$ protein). Novarom G, a dry commercial preparation of pectinase, and $\beta$-1,4-glucosidase (80 BGDU/g) derived from $A$. niger were obtained from NOVO Nordisk $A / S$, Bagsvaerd, Denmark. One $\beta$-glucosidase unit, 1 BGDU, liberates $1 \mu \mathrm{mol}$ of $\mathrm{p}$-nitrophenol from $\mathrm{p}$-nitrophenol- $\beta$ glucopyranoside (pNPG) per min at $23^{\circ} \mathrm{C}$ and $\mathrm{pH} 3.5$. Ethyl acetate was used to dissolve indigo (maximum absorbance $600 \mathrm{~nm}$ ).

2.2. Plant Culture. Polygonum tinctorium was grown under field conditions at the Experimental Centre of the Dipartimento di Agronomia e Gestione dell'Agroecosistema, University of Pisa (Pisa, Central Italy, $43^{\circ} \mathrm{N}$ latitude; $10^{\circ} \mathrm{E}$ longitude). The seed of a selected $\mathrm{P}$. tinctorium line was sown in a cold greenhouse in March 2002, and the resulting 4-week-old plants were transplanted to deep loam soil (clay $23 \%$, silt $24 \%$, sand $53 \%$, total nitrogen $1.04 \%$ o $\mathrm{pH} 8.2$, organic matter $1.56 \%$ ) in four replicated plots $20 \mathrm{~m}^{2}$ each, with inter-row and interplant spacing of $0.3 \mathrm{~m}$ and $0.3 \mathrm{~m}$, respectively. Fertilizer was applied at soil preparation, at rates of 100/100/100 $\mathrm{kg} \mathrm{ha}^{-1}$ of N/P/K and further $50 \mathrm{~kg} \mathrm{ha}^{-1}$ of $\mathrm{N}$ was applied after each harvest. Plants were maintained under optimal water supply conditions by a drip line-sourcelaterals irrigation system.

2.3. Extraction. Entire leaves were put into a glass beaker, and deionized water was added in a 1:10 weight: volume ratio. The extraction was conducted at temperatures of 100 and $25^{\circ} \mathrm{C}$. The extraction at $100^{\circ} \mathrm{C}$ (extract A) was made in a boiling bath for $10 \mathrm{~min}$ to denature native $\beta$-glucosidase and to obtain a water extract containing unhydrolyzed indican. The second extraction (extract B) was made maintaining leaves in deionized water to extract for $72 \mathrm{~h}$ at $25^{\circ} \mathrm{C}$ in order to evaluate indican hydrolysis by native $\beta$-glucosidase. Leaves were held under water to exclude air, thus maintaining anaerobic conditions. At the end of extraction, the extract was filtered, and an aliquot was centrifuged at 18000 $\mathrm{rpm}$ for $3 \mathrm{~min}$. The supernatant was diluted 1:10 (v/v) and injected into the HPLC system to evaluate the amount of unhydrolyzed indican. All extraction experiments were repeated three times using $500 \mathrm{~g}$ of fresh leaves.

2.4. Identification and Quantification of Indican by HPLC-ELSD. Leaf water extracts were diluted 1:10 ( v/v) with water, and $20 \mu \mathrm{L}$ was injected into the HPLC system (J asco PU 980) coupled with an evaporative light scattering detector (ELSD 2000, Alltech). Following the HPLC conditions described by Gilbert et al. (8) for indigo

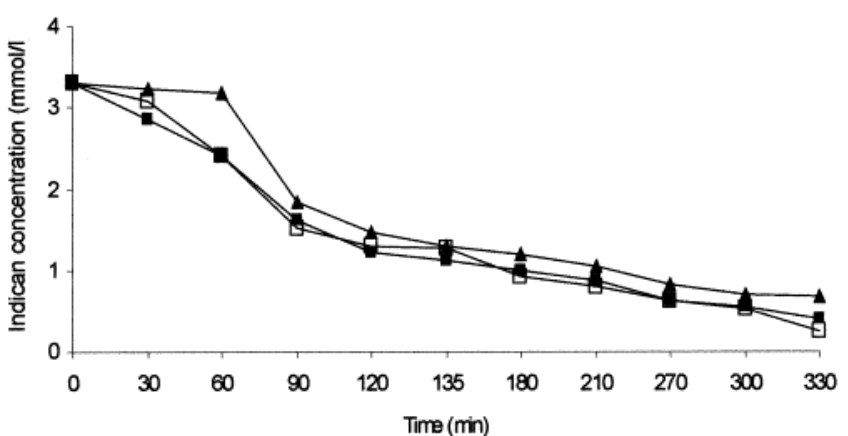

Figure 1. Time course of indican hydrolysis of $100{ }^{\circ} \mathrm{C}$ water extract of $\mathrm{P}$. tinctorium fresh leaves. Three different concentrations of $\beta$-glucosidase from Novarom G preparation [0.40 ( $\mathbf{\Delta}$ ), 1.5 ( $\square$ ) and 3.03 (ם) BGDU/ $/ \mu \mathrm{mol}$ indican] were tested in three $50-\mathrm{mL}$ subsamples of the extract. Reactions were carried out at $25{ }^{\circ} \mathrm{C}$, and indican content was determined by the HPLCELSD method described in Experimental Procedures.

precursors determination in I satis tinctoria, indican was separated on a X-Terra RP18 $3.5 \mu \mathrm{m}$ Waters column. Each analysis was performed in isocratic conditions using a solution of $68 \% \mathrm{H}_{2} \mathrm{O}, 32 \%$ acetonitrile, $1 \%$ oformic acid with a flow rate of $0.8 \mathrm{~mL} / \mathrm{min}$. The detector program was set to a drift tube temperature of $107^{\circ} \mathrm{C}$, gas flow 2.7 SLPM, attenuation 2/5, and impactor off. Chromatograms were acquired online, and data were collected via a J asco-I nterface (Hercule 2000) and analyzed using a J asco-B orwing 2000 data system. The indican peak was identified using synthetic indican from Sigma $(95 \%$ purity) dissolved in water and quantified by a calibration curve (indican concentration vs peak area) that was obtained from serial dilutions of a stock solution (100 $\mu \mathrm{g}$ $\mathrm{mL}^{-1}$ ) of synthetic indican in water injected into the HPLC. The theoretical indigo amount obtainable if all indoxyl molecules had reacted to form indigo molecule was determined by stoichiometric calculations.

2.5. Indican Seasonal Variation. The changes in photosynthetically active radiation (PAR) in the 400$700 \mathrm{~nm}$ waveband were recorded along the growing season with the hel $p$ of a weather station, equipped with a data logger (Campbell CRX10) that acquires PAR as $\mu \mathrm{mol}$ photons $\mathrm{m}^{-2}$ and global radiation $\left(\mathrm{KJ} / \mathrm{m}^{2}\right)$ values on hourly and daily bases. The Quantum Sensor system is model Rg19 supplied by Silimet Co. (Modena, I taly). Every 15 days from transplanting, fully expanded mature leaf samples $(n=20)$ from the upper part of the canopy were taken from each plot for extraction.

2.6. E nzyme Assays. 2.6.1. Evaluation of Novarom G Activity. To evaluate the optimal enzyme amount to achieve total hydrolysis of indican, preliminary work was done with a $100{ }^{\circ} \mathrm{C}$ aqueous extract of $\mathrm{P}$. tinctorium fresh leaves. Novarom G $(82.7,312.5$, and $625 \mathrm{mg})$ was added to three 50-mL subsamples of the extract to obtain a 0.40 , 1.5 , and 3.03 BGDU/ $\mu \mathrm{mol}$ indican concentration, respectively. Indican hydrolysis was followed at $25^{\circ} \mathrm{C}$, and indican content was quantified by HPLC-ELSD. From these determinations we decided to use a $\beta$-glucosidase concentration of $3.03 \mathrm{BGDU} / \mu \mathrm{mol}$ indican (Figure 1). 


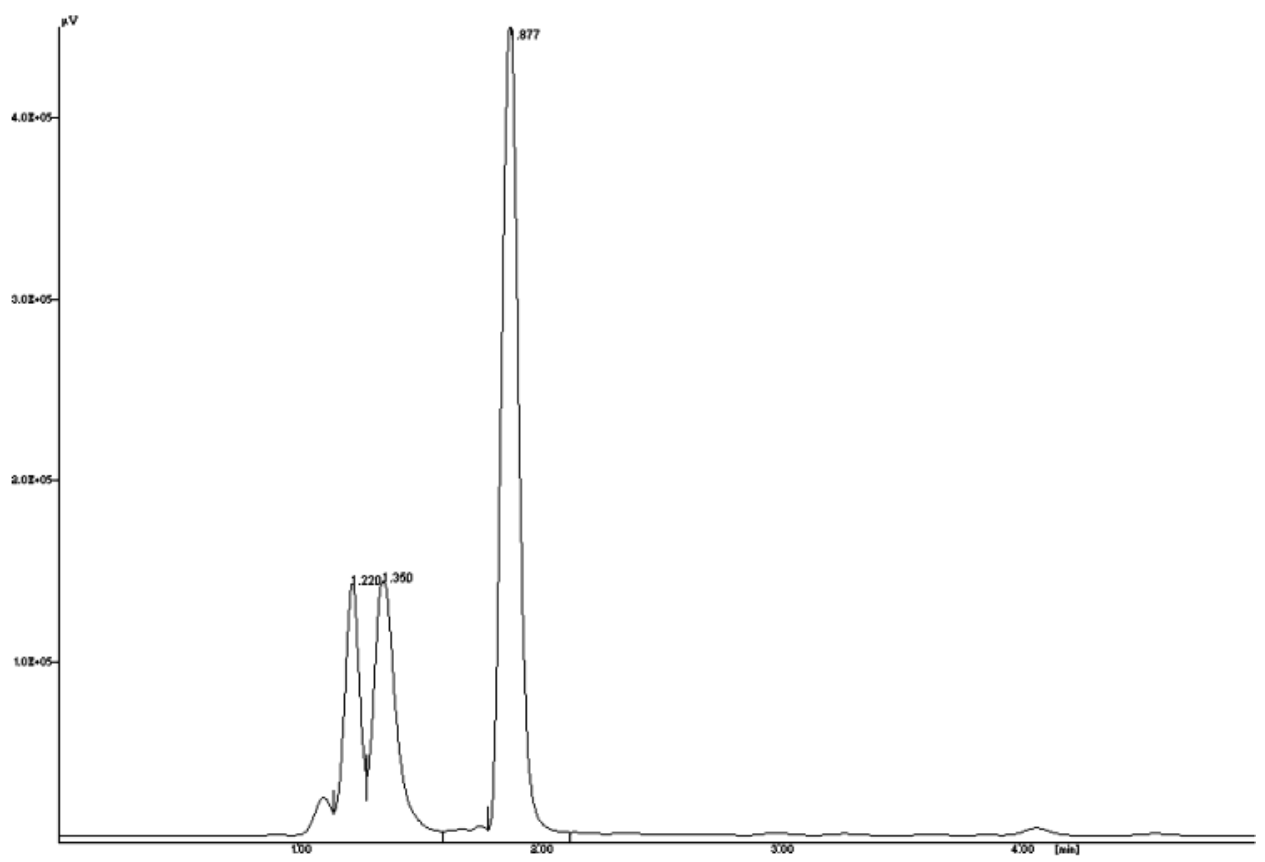

Figure 2. Typical P. tinctorium $100^{\circ} \mathrm{C}$ water extract chromatogram recorded with an ELS detector as described in Experimental Procedures. The peak at $t_{R} 1.87$ is identified as indican, and the peak at $t_{R} 1.35$ was identified as glucose. Leaves were sampled at the beginning of J uly.

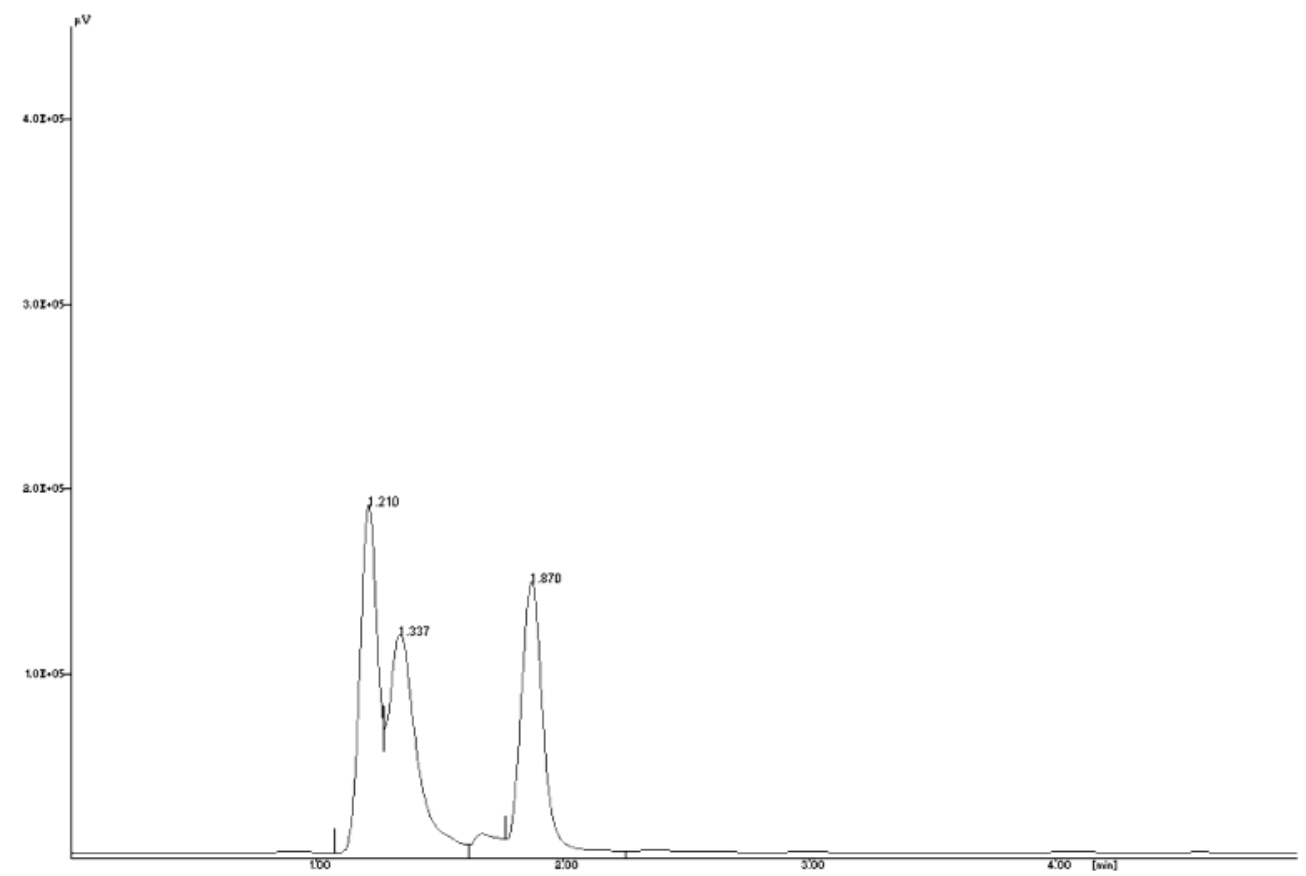

Figure 3. Typical $\mathrm{P}$. tinctorium $100{ }^{\circ} \mathrm{C}$ water extract chromatogram recorded with an ELS detector as described in Experimental Procedures. The peak at $t_{R} 1.87$ is identified as indican, and the peak at $t_{R} 1.35$ was identified as glucose. Leaves were sampled in September.

2.6.2. Evaluation of Almond $\beta$-Glucosidase and Novarom G Acti vity. $\beta$-Glucosidase activity was determined using both standard indican solution (a) and Polygonum tinctorium leaf extract A (b) as substrate.

(a) Two $3.2 \mathrm{mM}$ solutions (S1 and S2) of standard indican were prepared by dissolving $47.5 \mathrm{mg}$ of standard indican in $50 \mathrm{~mL}$ of a $\mathrm{CH}_{3} \mathrm{COOH} / \mathrm{CH}_{3} \mathrm{COONa}$ buffer solution $(50 \mathrm{mM}), \mathrm{pH} 5.0$, and $50 \mathrm{U}$ of almond $\beta$-glucosidase or Novarom G was added to the S1 and S2 solutions, respectively. The solutions were stirred, indican hydrolysis reaction was followed at $25{ }^{\circ} \mathrm{C}$, and indican content was quantified by HPLC-ELSD.

(b) $\mathrm{CH}_{3} \mathrm{COOH} / \mathrm{CH}_{3} \mathrm{COONa}$ buffer $(50 \mathrm{mM}$, pH 5) was added to extract $\mathrm{A}$. F ifty mililiters of subsamples (S3 and S4) from the buffer were added with $50 \mathrm{U}$ of almond $\beta$-glucosidase and Novarom G, respectively. Solutions were stirred, indican hydrolysis reaction was followed at $25^{\circ} \mathrm{C}$, and indican content was quantified by HPLCELSD. Both substrates showed a blue color after a few minutes of stirring. At the end of hydrolysis (5-6 h), when indican content was negligible, solutions were left at room temperature overnight to allow newly formed indigo to settle.

Fifty units of Novarom $\mathrm{G}$ was added to $50 \mathrm{~mL}$ of extract A1 and $A 2$, previously described, to allow formation of 


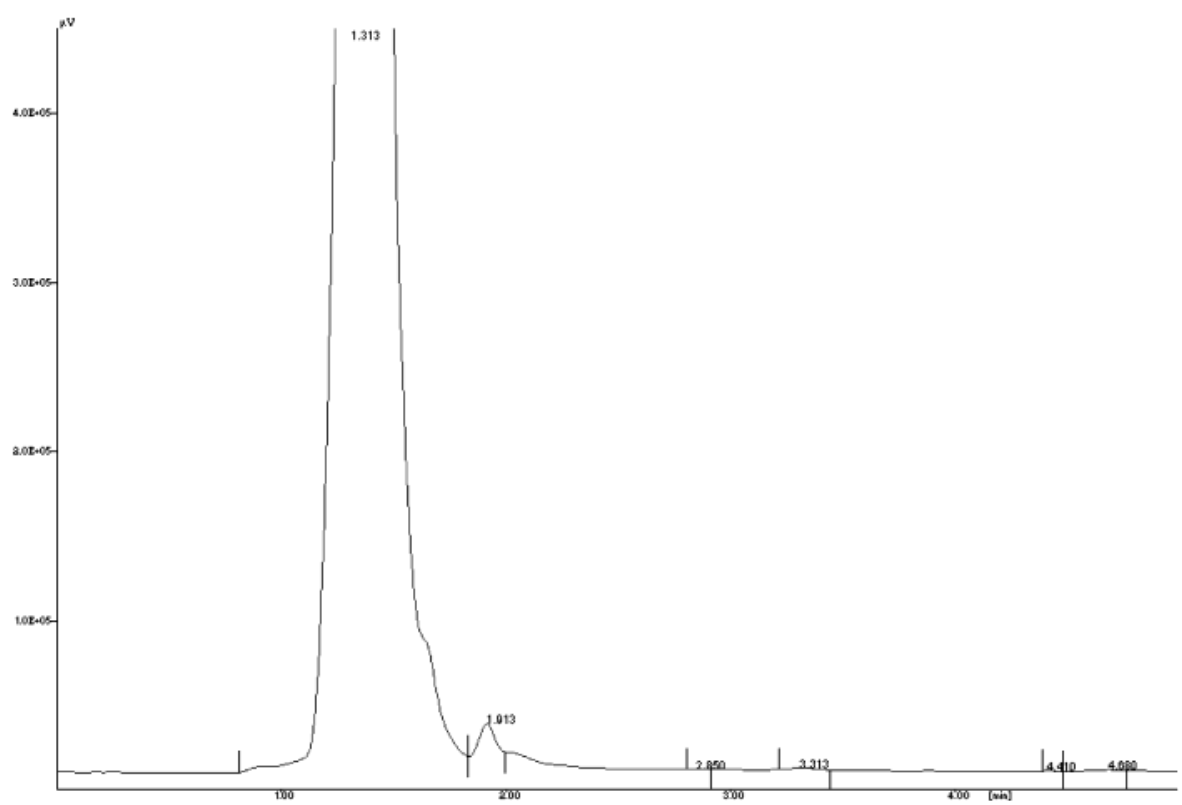

Figure 4. P. tinctorium $100{ }^{\circ} \mathrm{C}$ water extract chromatogram $5 \mathrm{~h}$ after adding $\beta$-glucosidase. Indican peak decreased while the glucose peak increased.

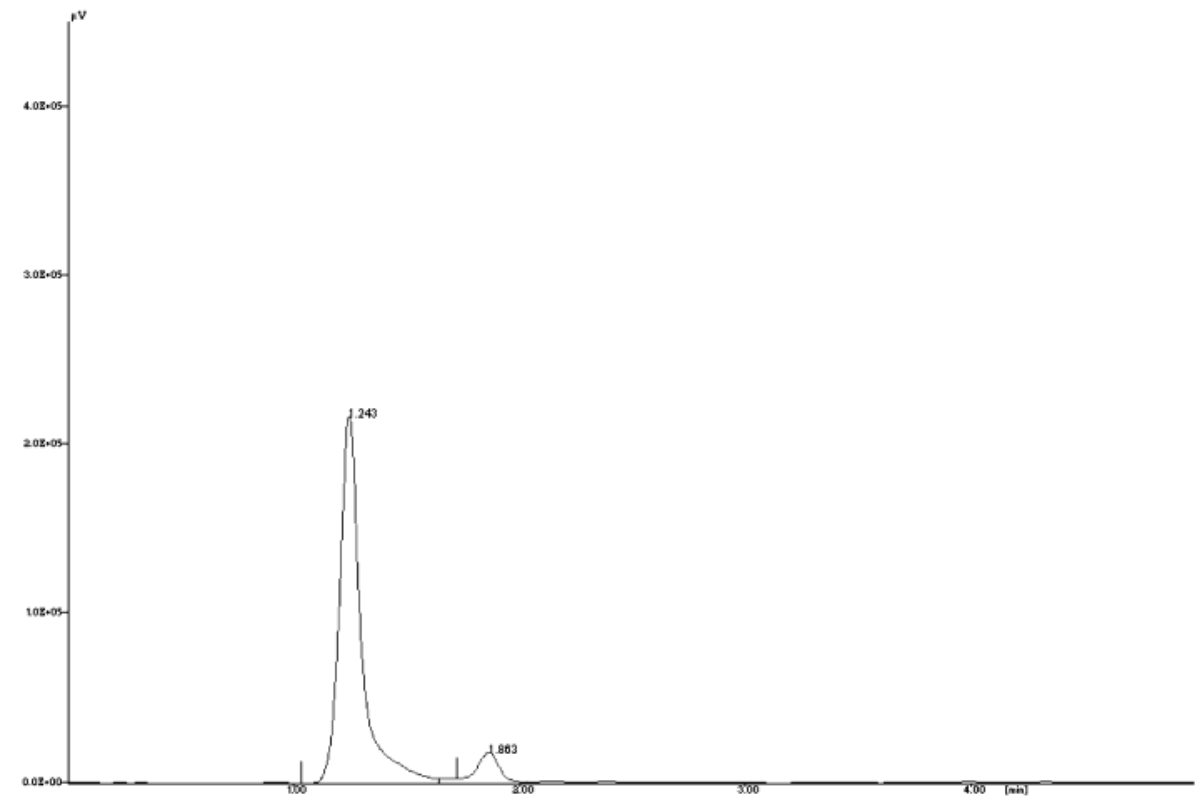

Figure 5. P. tinctorium $25^{\circ} \mathrm{C}$ water extract chromatogram after 3 days. Indican was hydrolyzed by native $\beta$-glucosidase while glucose accumulated.

indigo, which was quantified spectrophotometrically. Each hydrolysis experiment was repeated three times.

2.7. Indigo Quantification by Spectrophotometric Analysis. Indigo content was determined according to Stoker et al. (9). An appropriate amount ( $2 \mathrm{~mL}$ ) of extract $\mathrm{B}$ was added with $\mathrm{Ca}(\mathrm{OH})_{2}$ to adjust the $\mathrm{pH}$ to 11 , and then the mixture was aerated using a small compressor until a blue color developed. Successively, an aliquot (0.5 $\mathrm{mL}$ ) of the basic solution was taken and mixed with 2 $\mathrm{mL}$ of water and $2 \mathrm{~mL}$ of ethyl acetate. After stirring, the indigo content of the blue upper phase was determined spectrophotometrically at $600 \mathrm{~nm}$ using a calibration curve obtained from the absorbance of serial dilutions of standard indigo in ethyl acetate. For each sample photometric measurement was carried out in triplicate.

\section{Results and Discussion}

3.1. Identification and Quantification of Indican by HPLC-ELSD. In Figures 2 and 3, typical P. tincto- rium $100{ }^{\circ} \mathrm{C}$ water extract (leaves sampled in J uly and September, respectively) chromatograms are presented. The indican peak is the third one, with a retention time $\left(t_{R}\right)$ of $1.87 \mathrm{~min}$; the second peak ( $t_{R}$ about $1.35 \mathrm{~min}$ ) was identified as glucose by comparison with standard glucose. The peak at $t_{R} 1.2$ was not identified. Using the method described in section 2.4, a good resolution in a short run time was consistently obtained. When $\mathrm{P}$. tinctorium leaves were extracted at $100{ }^{\circ} \mathrm{C}$ and $\beta$-glucosidase was added, the indican peak almost completely disappeared over a $5 \mathrm{~h}$ period, with a corresponding increase in the glucose peak, indicating that indican hydrolysis had occurred (Figure 4). On the other hand, in a $25^{\circ} \mathrm{C}$ water extract native $\beta$-glucosidase hydrolyzes indican as soon as the precursor was extracted from the leaves, and after $72 \mathrm{~h}$ the amount of precursor detectable was negligible (Figure 5).

3.2. Indican Seasonal Variation. In P. tinctorium indican content changed with the growing season along 


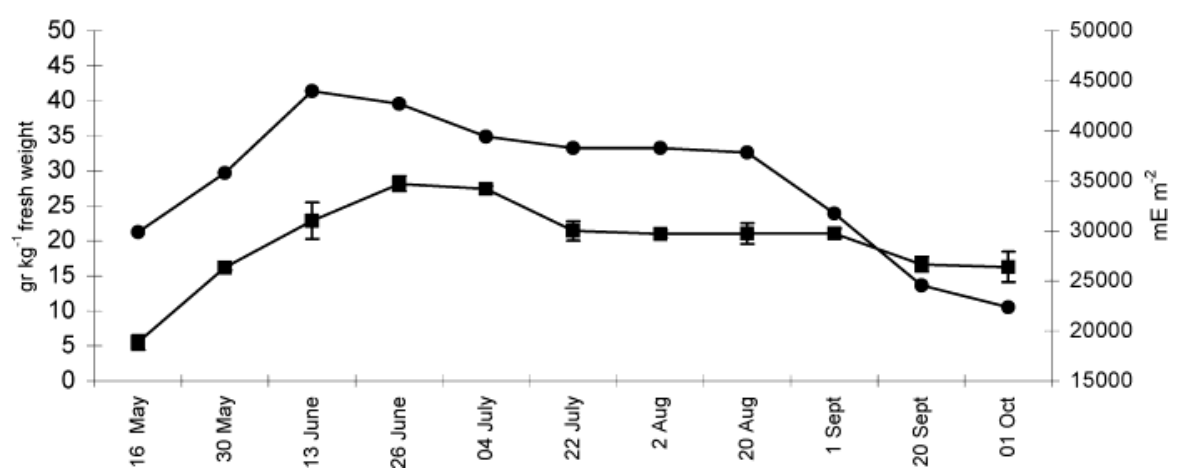

Figure 6. Seasonal variation of indican $(\boldsymbol{\square})$ in $P$. tinctorium leaves in relation to total daily PAR $(\bullet)$ in $\mathrm{mE}^{-2}(E=E$ instein, corresponding to 1 mols of photons). Fully expanded mature leaves from the upper part of the plants were sampled every 15 days from May to October. Extraction and quantification were performed as described in Experimental Procedures.

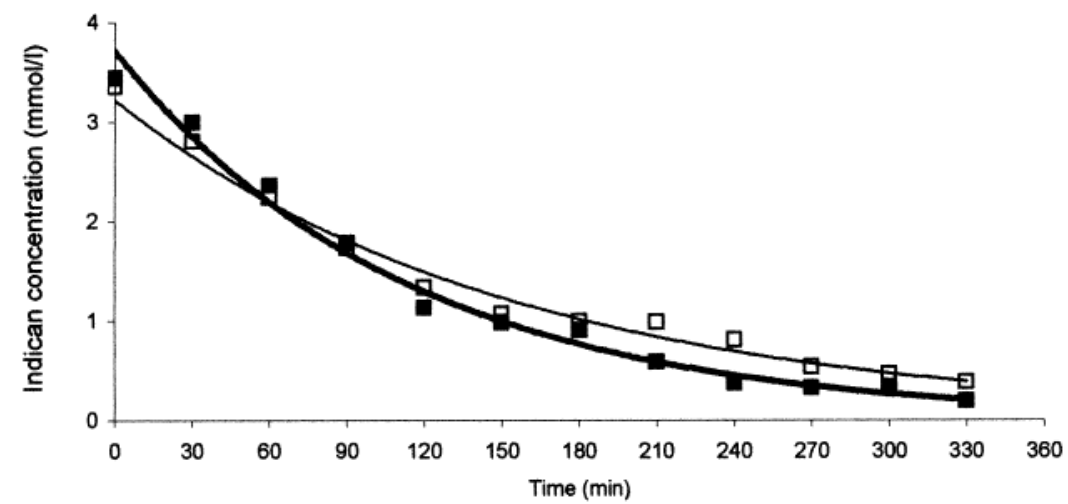

Figure 7. Time course of indican hydrolysis of two $3.2 \mathrm{mM}$ solutions of standard indican (S1 and S2) prepared dissolving $47.5 \mathrm{mg}$ of indican in $50 \mathrm{~mL}$ of a $\mathrm{CH}_{3} \mathrm{COOH} / \mathrm{CH}_{3} \mathrm{COONa}$ buffer solution $(50 \mathrm{mM})$, pH 5.0. Fifty units of almond $\beta$-glucosidase or $\mathrm{N}$ ovarom G was added to S1 ( $\square$ ) and S2 ( $\square$ ) solutions respectively, and reaction was followed at $25^{\circ} \mathrm{C}$ by HPLC-ELSD.

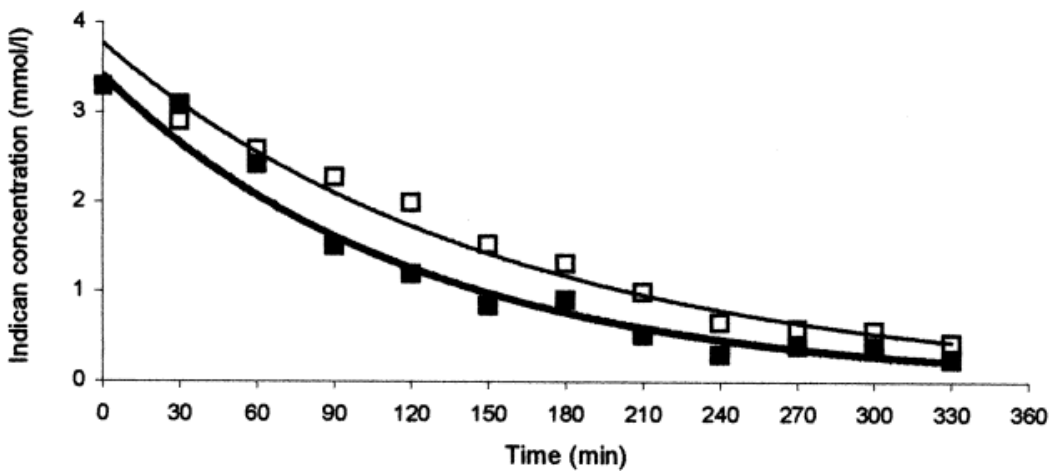

Figure 8. Time course of indican hydrolysis of $100{ }^{\circ} \mathrm{C}$ water extract of $\mathrm{P}$. tinctorium fresh leaves added with a $\mathrm{CH}_{3} \mathrm{COOH} \mathrm{CH}_{3}$ COONa buffer solution (50mM) to maintain pH 5.0. Fifty units of almond $\beta$-glucosidase or Novarom $\mathrm{G}$ was added to 50 -mL subsamples, S3 ( $\square$ ) and S4 ( $\square)$, of buffer solution, and reaction was followed by HPLC-ELSD at $25^{\circ} \mathrm{C}$.

with plant development. It increased from $5.48 \mathrm{~g} \mathrm{~kg}^{-1}$ FW in May, when plants were at eight true leaves stage, to $28 \mathrm{~g} \mathrm{~kg}^{-1} \mathrm{FW}$ at the end of J une to the beginning of J uly, when plants gained approximately $60 \mathrm{~cm}$ height and completed their vegetative development. Pol ygonum tinctorium behaves as a short-day plant, and at our latitudes flowering took place mostly from mid-J uly (day length $14 \mathrm{~h} 57 \mathrm{~min}$ ) to the beginning of August (daylength $14 \mathrm{~h} 16 \mathrm{~min}$ ). Indican decreased with the onset of flowering and then remained stable at about $20 \mathrm{~g} \mathrm{~kg}^{-1}$ FW until the end of August. It further decreased to about $15 \mathrm{~g} \mathrm{~kg}^{-1} \mathrm{FW}$ during seed formation and filling in September-October, when leaves become reddish. Changes in PAR ( $\mathrm{mE} \mathrm{m}^{-2}$ day $\left.^{-1}\right)$ during the growth of the plant was shown to affect the indican production as showed in Figure 6. The highest indigo precursor values were recorded at the end of J une, with the highest PAR intensities and longer day length. In relation to the main environmental parameters of air temperature, day length, and PAR, this region appears to be suitable for this crop, producing high indigo precursor content.

3.3. Enzyme Assays. The two enzyme preparations, Novarom G and sweet almond $\beta$-glucosidase, showed a similar ability to hydrolyze indican both in the standard solutions (Figure 7) and in the $100{ }^{\circ} \mathrm{C}$ water extract (Figure 8). After $5 \mathrm{~h}$, indican was almost completely hydrolyzed by both enzyme preparations until similar negligible amount $(0.25-0.44 \mathrm{mmol} / \mathrm{L})$ remained. From a similar initial amount (3.29-3.33 $\mathrm{mmol} / \mathrm{L})$ of indican, before adding enzyme, $1.26-1.35 \mathrm{mmol} / \mathrm{L}$ theoretical indigo can be obtained (Table 1 ).

Theoretical indigo values were compared with indigo quantified by spectrophotometric analyses. The amount of indigo obtained from each enzyme assay was lower than theoretical values: $0.149,0.271,0.202$, and 0.328 $\mathrm{mmol} / \mathrm{L}$ for S1, S2, S3, and S4 respectively (Table 2). It 
Table 1. HPLC-ELSD Results

\begin{tabular}{|c|c|c|c|c|}
\hline & $\mathrm{S}^{\mathrm{C}}$ & $\mathrm{S} 2^{\mathrm{C}}$ & $\mathrm{S}^{\mathrm{c}}$ & $\mathrm{S} 4^{\mathrm{C}}$ \\
\hline $\begin{array}{l}\text { indican concn before adding the enzyme }(\mathrm{mM}) \\
\text { unhydrolyzed indican at the end of hydrolysis }(\mathrm{mM})^{\mathrm{a}} \\
\text { indigo }(\mathrm{mM})^{\mathrm{b}}\end{array}$ & $\begin{array}{l}3.33 \pm 0.300 \\
0.30 \pm 0.002 \\
1.33 \pm 0.18\end{array}$ & $\begin{array}{l}3.30 \pm 0.211 \\
0.32 \pm 0.005 \\
1.32 \pm 0.20\end{array}$ & $\begin{array}{l}3.29 \pm 0.15 \\
0.44 \pm 0.008 \\
1.26 \pm 0.15\end{array}$ & $\begin{array}{l}3.29 \pm 0.25 \\
0.25 \pm 0.003 \\
1.35 \pm 0.21\end{array}$ \\
\hline
\end{tabular}

${ }^{a}$ Indican content $5 \mathrm{~h}$ after addition of enzyme. ${ }^{\mathrm{b}}$ Theoretical indigo determined stoichiometrically from complete reaction of free indoxyl ( 1 mol indican $\rightarrow 1 \mathrm{~mol}$ indoxyl $\rightarrow 0.5 \mathrm{~mol}$ indigo $\Rightarrow$ mmole theoretical indigo $=0.5$ (mmol indican)). Data are average of three hydrolysis experiments. ${ }^{\mathrm{C}} \mathrm{S} 1$ : standard indican solution with almond $\beta$-glucosidase. S2: standard indican solution with $\mathrm{Novarom}$ G. S3: $100{ }^{\circ} \mathrm{C}$ water extract with almond $\beta$-glucosidase. S4: $100{ }^{\circ} \mathrm{C}$ water extract with Novarom $\mathrm{G}$ as described in Experimental Procedures.

Table 2. Indigo (mM, mean \pm SE) Determined Spectrophotometrically from Enzymatically Hydrolyzed Solutions (S1, S2, S3, and S4) in Comparison with $25^{\circ} \mathrm{C}$ Water Extract (B)

\begin{tabular}{|c|c|c|c|c|c|}
\hline & \multicolumn{5}{|c|}{ indigo content $^{\mathrm{a}}$} \\
\hline & S1 & $\mathrm{S} 2$ & S3 & S4 & extract $\mathrm{B}^{\mathrm{C}}$ \\
\hline significanceb; LSD $0.05=0.043$ & $\begin{array}{l}0.137 \pm 0.008 \\
\mathrm{e}\end{array}$ & $\begin{array}{l}0.259 \pm 0.012 \\
C\end{array}$ & $\begin{array}{l}0.198 \pm 0.013 \\
d\end{array}$ & $\begin{array}{l}0.328 \pm 0.012 \\
\mathrm{~b}\end{array}$ & $\begin{array}{l}0.409 \pm 0.020 \\
a\end{array}$ \\
\hline
\end{tabular}

a Measurements done at the end of indican hydrolysis (statistics are basied on replicates of three hydrolysis experiments). ${ }^{\mathrm{b}}$ significant at $99.9 \%$ level from one way ANOVA analysis. Means followed by a common letter are not significantly different at $1 \%$ level according to

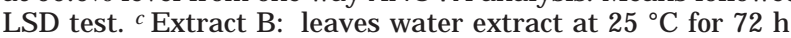

is difficult to explain why there was so much difference between these values. Presumably the indigo formed is less than $100 \%$ because of incomplete conversion of indoxyl to indigo. This can be due to side reactions of the reactive indoxyl and indoxyl free radical with other secondary metabolites present; it can also be due to indoxyl isomerization to isatin and the formation of indirubin (10).

Furthermore, solutions with sweet almond $\beta$-glucosidase (S1 and S3) gave an indigo amount lower than that produced by Novarom G (S2 and S4), even if the theoretical indigo was nearly the same. The use of Novarom G led to a better exploitation of formed indoxyl for indigo production (Table 2 ).

At $25^{\circ} \mathrm{C}$ (extract B) indican hydrolysis was completed after $72 \mathrm{~h}$ and $0.59 \mathrm{mmol} / \mathrm{L}$ of unhydrolyzed indican was found. For this extract a higher amount of indigo was obtained $(0.409 \mathrm{mmol} / \mathrm{L}$, spectrophotometrically determined) with respect to the S1-S4 solutions. Even if we could not compare the activity of the endogenous $\beta$-glucosidase with enzyme preparations (as the methods of extraction were different), results showed that the extraction at room temperature is the most useful.

\section{Conclusions}

A rapid and reliable HPLC-ELSD method to determine indican content in $\mathrm{P}$. tinctorium leaves was performed. Indigo precursor content is highest in late J une, following with a delay of about the 2 weeks the measured increase in PAR. This is followed by a period in which precursor levels remain stable until the end of August. After this time the rapid decrease in PAR is followed by a decreased precursor content. We conclude that maximum indigo yields will come from harvest within the period J une to August influenced by light intensity and plant development stage, with higher values in the summer months. Results showed that this method can be used to determine the best time to harvest the crop for the optimum yield of indigo from indican. The present paper extends the previous work of Maugard et al. (5) by showing that the two enzyme preparations had a similar hydrolysis strength but an increasing ability to promote indigo formation in the order almond $\beta$-glucosidase $>$ Novarom $\mathrm{G}$. Otherwise an improved indigo amount is obtained using the extraction at room temperature and the native $\beta$-glucosidase. These results can be applied to optimize indigo production in industrial applications.

\section{Acknowledgment}

The authors wish to thank the EC for funding for this work through the Framework $\mathrm{V}$ grant: SPINDIGO QLK5-CT-2000-30962. The authors gratefully acknowledge Dr. R.Risaliti, Dr. C. Bertanza, Dr. D. Pogliani, and Mr. Luciano Pulga for their technical assistance.

\section{References and Notes}

(1) Minami, Y.; Takao, H.; Kanafuji, T.; Miura, K.; Kondo, M.; Hara-Nishimura, I.; Nishimura, M.; Matsubara, H. $\beta$-Glucosidase in the indigo plants: intracellular localisation and tissue specific expression in leaves. Plant Cell Physiol. 1997, 38 (9), 1069-1074.

(2) Minami, Y.; Kanafuji, T.; Miura, K. Purification and characterisation of a $\beta$-glucosidase from Polygonum tinctorium, which catalyses preferentially the hydrolysis of indican. Biosci. Biotechnol. Biochem. 1996, 60, 147-149.

(3) Balfour-Paul, J. Indigo; British Museum Press, London, 1998; pp 115-145

(4) Cardon, D.; Du Chatenet, G. Guidedes Teintures Nature les; Perret, D., Ed.; Neuchatel: Paris, 1990; pp 133-154.

(5) Maugard, T.; E naud, E.; de La Sayette, A.; Choisy, P.; Legoy, M. D. $\beta$-Glucosidase-catalysed hydrolysis of indican from leaves of Polygonum tinctorium. Biotechnol. Prog. 2002, 18, 1104-1108.

(6) Stockwell P. B.; King B. W. A light scattering detector for liquid chromatography. Am. Lab. 1991, 19-24.

(7) Mancini F.; Miniati E.; Montanari L. Performance of some evaporative light scattering detectors (ELSD) in the analysis of triglycerides and phospholipids. Ital. J . Food Sci. 1997, 9, 323-334.

(8) Gilbert, K. G.; Maule, H G.; Rudolph, B.; Lewis, M.; Vandenburg, H.; Sales, E.; Tozzi, S.; Cooke, D. T. Quantitative analysis of indigo-precursors in leaves of Isatis spp. Manuscript in preparation.

(9) Stoker, K.; Cooke, D. T.; Hill, D. J . An improved method for the large-scale processing of woad (I satis tinctoria) for possible commercial production of woad indigo. J . Agric. Eng. Res. 1998, 71, 315-320.

(10) Russell, G. A.; Kaupp, G. Oxidation of Carbanions. IV. Oxidation of indoxyl to indigo in basic solution. J . Am. Chem. Soc. 1969, 91, 3851-3858

Accepted for publication J uly 10, 2003.

BP0300218 